\title{
Soil water deficit and recovery under different vegetation types on the Chinese Loess Plateau
}

\author{
Mingshuang Shen ${ }^{1}$, Yang $\mathrm{Yu}^{1}$, Shouhong Zhang ${ }^{1}$, Ruoxiu Sun ${ }^{1}$, Zhengle Shi ${ }^{1}$, Yawei $\mathrm{Hu}^{1}$, \\ and jianjun Zhang $^{1}$ \\ ${ }^{1}$ Beijing Forestry University
}

December 21, 2021

\begin{abstract}
Characterizing soil water content (SWC) dynamics is a prerequisite for conducting sustainable vegetation restoration on the Chinese Loess Plateau. However, quantifying the variations of the SWC in the deep soil layers remains a challenge because of the different driving factors and the complexity of surface processes. In this study, SWC in $0-10 \mathrm{~m}$ of artificial forestlands $(\mathrm{AF})$, apple orchard $(\mathrm{AO})$, native forestland (NF), farmland (maize; FL), and native grassland (NG) were monitored during 2019-2020. The deficit size (DS) and recovery index (RI) were used to explore the effects of vegetation types on SWC. The results showed that the SWCs of forestlands were significantly lower than the SWC of native grassland (12.32\%) and tree species significantly affected the SWC. The monthly DS values in forestlands were negative, while those of FL were positive. The DS value in $0-10 \mathrm{~m}$ and predictive values below $10 \mathrm{~m}$ were negative of forestlands. Thus, tree planting may have consumed soil water at a depth of $>10 \mathrm{~m}$. During the investigation period, soil water was restored in $0-1 \mathrm{~m}$ with the positive RI values. In addition, artificial forestlands showed good performance in deep soil water recovery. Canopy density was the controlling factor for soil water restoration. Our results demonstrated that the current afforestation mode used more soil water but was conducive to deep soil water conservation. Therefore, reasonable adjustments should be made according to the local soil and water resources for future vegetation selection and management.
\end{abstract}

\section{Hosted file}

Manuscript.docx available at https://authorea.com/users/452049/articles/550198-soil-waterdeficit-and-recovery-under-different-vegetation-types-on-the-chinese-loess-plateau

\section{Hosted file}

Figures.docx available at https://authorea.com/users/452049/articles/550198-soil-waterdeficit-and-recovery-under-different-vegetation-types-on-the-chinese-loess-plateau 